\title{
PENGARUH DIRECT MAIL DAN TELEMARKETING TERHADAP KEPUTUSAN PEMBELIAN PAKET UMRAH RAKA TOURS AND TRAVEL
} (Survey Terhadap Pengguna Paket umrah Raka Tours and Travel)

\author{
Nurmala Dewi \\ Ridwan Purnama \\ Rini Andari \\ Manajemen Pemasaran Pariwisata FPIPS UPI
}

\begin{abstract}
One type of tourism has great potential. Umrah and Hajj is a popular type of religious tourism in Indonesia. The potential is rated high because the majority of Indonesia's population is Muslim. Given this also emerging cooperation between Indonesia and Saudi Arabia as a tourist destination more closely. One of them with the cooperation of the travel-travel in Indonesia with travel that is in Saudi Arabia. This of course affects the number of trips efforts in several major cities in Indonesia, one of which the city of Bandung. One travel agency Bandung is Raka Tours and Travel. Raka Tours and Travel is a BPW (Travel Bureau), which is engaged in servicing a variety of travel needs, such as the sale of air transportation tickets, hotel vouchers, travel packages, various services of travel documents, MICE and religious journey that umrah and hajj. Raka Tours umrah package sales decreased from 2010 to 2011. The sales decline Raka Tours umrah package is reached -14.55\%. Direct marketing especially in direct mail and telemarketing is one of the strategies that can be used to increase sales.In this regard it is done research on the effect of direct mail and telemarketing to purchasing decision umrah package. Step - step Direct Marketing consists of direct mail (direct mail) and telemarketing (selling over the phone).Type of research is descriptive and verification methods used are cross sectional method with the sample size using the formula iteration, the obtained sample size of 110 respondents. The analysis technique used is multiple linear regression analysis with SPSS for windows 18:00. Based on the test results obtained by statistical findings of direct marketing in which all variables have an influence on purchase decisions that direct mail and telemarketing, it showed $65.15 \%$ have an influence on the purchase decision, while the remaining $34.85 \%$ influenced by other variables. Thus, the direct mail and telemarketing have a strong influence in influencing purchasing decisions Raka umrah package tours and Travel.
\end{abstract}

Keywords: Direct Mail, Telemarketing, Purchase Decision

\section{PENDAHULUAN}

\subsection{Latar Belakang}

Dalam beberapa dekade terakhir pariwisata merupakan salah satu bidang industry dengan pertumbuhan yang cukup signifikan. Beberapa jenis pariwisata berkembang pesat, salah satu diantaranya adalah wisata ziarah. Salah satu bentuk wisata ziarah dalam agama Islam adalah umrah dan haji. Dalam perkembangannya perjalanan umrah dan haji ini dilaksanakan melalui berbagai biro perjalanan wisata yang tersebar hampir di seluruh wilayah Indonesia, salah satunya Kota Bandung. Berikut merupakan data potensi usaha perjalanan wisata di kota Bandung tahun 2006-2011
TABEL 1.1

DATA POTENSI USAHA PERJALANAN WISATA DI KOTA BANDUNG TAHUN 2006-2011

\begin{tabular}{|c|c|c|}
\hline NO & TAHUN & JUMLAH \\
\hline 1 & 2006 & 158 \\
\hline 2 & 2007 & 170 \\
\hline 3 & 2008 & 182 \\
\hline 4 & 2009 & 197 \\
\hline 5 & 2010 & 216 \\
\hline 6 & 2011 & 221 \\
\hline
\end{tabular}

Sumber : Asita Bandung 2011 
Berdasarkan Tabel 1.1, potensi sekaligus perkembangan usaha perjalanan wisata di kota Bandung menunjukkan peningkatan hampir 6 tahun berturut-turut. Hal ini tentu saja membuktikan adanya peningkatan dan perkembangan yang positif dalam industri usaha perjalanan wisata. Berbagai wilayah di kota Bandung ikut berkembang, salah satunya adalah wilayah Bandung Timur, berikut merupakan market share biro perjalanan wisata penyedia paket umrah tahun 2011.

TABEL 1.2

MARKET SHARE BPW PENYEDIA PAKET UMRAH KAWASAN BANDUNG TIMUR TAHUN 2011

\begin{tabular}{|c|c|c|c|}
\hline \multirow{2}{*}{ No } & \multirow{2}{*}{ Nama } & \multicolumn{2}{|c|}{ Jumlah Jamaah } \\
\cline { 3 - 4 } & $\mathbf{2 0 1 0}$ & $\mathbf{2 0 1 1}$ \\
\hline 1 & PT. Amanah Mulia Wisata & 80 & 93 \\
\hline 2 & PT. Armada Suci & 208 & 205 \\
\hline 3 & PT. Kharisma Muzdzalifah & 90 & 118 \\
\hline 4 & PT. Raka Amal Utama & 198 & 145 \\
\hline 5 & $\begin{array}{c}\text { PT. Megacitra Intina } \\
\text { Mandiri }\end{array}$ & 134 & 105 \\
\hline 6 & PT. Qiblat tour & 65 & 69 \\
\hline
\end{tabular}

Sumber : Marketing Raka Tours and Travel 2011

Berdasarkan Tabel 1.2 diatas dapat dilihat bahwa diantaranya terdapat enam biro perjalanan wisata yang berada di kawasan Bandung Timur. Berdasarkan data tersebut juga terdapat 3 biro perjalanan wisata yang mengalami penurunan pada tahun 2011, salah satunya PT. Raka Amal Utama.

Menurunnya jumlah jamaah Raka Tours and Travel dikarenakan berbagai faktor yan menyebabkan Raka Tours and Travel belum dapat menambah maupun mempertahankan jumlah jamaah seperti perusahaan travel lainnya. Hal ini tentu saja berimbas pada penjualan paket-paket umrah yang dimiliki perusahaan, salah satunya paket umrah. berikut data jumlah penjualan paket umrah tahun 2006-2011.

\section{GAMBAR 1.1 \\ JUMLAH JAMAAH IBADAH UMRAH \\ RAKA TOURS \& TRAVEL TAHUN 2006-2011}

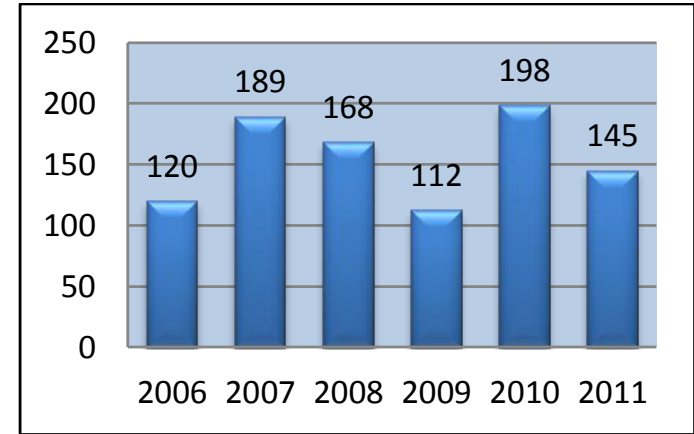

Sumber : Accounting Raka Tours and Travel 2011

Penurunan-penurunan yang terjadi setiap tahunnyatentu saja berdampak negatif pada target yang dimiliki perusahaan. Penurunan jumlah jamaah umrah tersebut perlu dikaji penyebabnya. Beberapa penyebab tersebut diantaranya tidak adanya staff yang secara langsung juga khusus menangani bagian marketing paket ibadah Umrah, program-program promosi yang ada tidak dilaksanakan secara terus-menerus dan berkesinambungan, juga kurangnya respon positif dari calon jamaah terhadap paket umrah yang dimiliki menjadi faktor-faktor mengapa penurunan dapat terjadi, berikut Tabel 1.3 mengenai paket perjalanan umrah Raka Tours and Travel tahun 2011.

TABEL 1.3

PAKET PERJALANAN UMRAH RAKA TOURS \& TRAVEL 2011

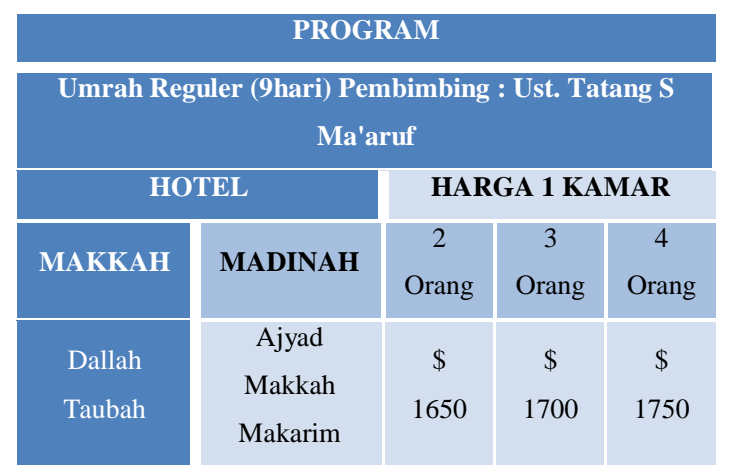

Sumber : Data Raka Amal Utama (Raka Tours \& Travel)

Berdasarkan data pembelian paket umrah, paket ini ternyata kurang dapat menarik minat para calon jamaah selain itu promosi yang dilaksanakan perusahaan tidak sebaik yang dilakukan pada tahun sebelumnya. Dalam perkembangannya sebagai sebuah biro perjalanan wisata, 
kurangnya daya tarik terhadap paket umrah yang tersedia dan berimbas pada penurunan jumlah jamaah ini dikhawatirkan akan berlanjut pada tahun-tahun selanjutnya. Hal tersebut telah berdampak pada jumlah pengguna paket umrah Raka Tours and Travel pada dua kantor cabang lain yaitu daerah Bukittinggi, Lampung serta kota Bandung sendiri sebagai kantor pusat mengalami penurunan. Hal ini dapat dibuktikan pada Tabel 1.4 berikut ini :

\section{TABEL 14}

JUMLAH PENGGUNA PAKET UMRAH BERDASARKAN KANTOR PERWAKILAN TAHUN 2007-2011

\begin{tabular}{|c|c|c|c|c|c|}
\hline \multirow[b]{2}{*}{ Tahun } & \multicolumn{3}{|c|}{ KANTOR PERWAKILAN } & \multirow[b]{2}{*}{ Total } & \multirow[b]{2}{*}{ Presentase } \\
\hline & BDG & $\begin{array}{l}\text { Bukit } \\
\text { tinggi }\end{array}$ & Lampung & & \\
\hline 2007 & 55 & 30 & 14 & 189 & $23.20 \%$ \\
\hline 2008 & 68 & 69 & 32 & 169 & $20.70 \%$ \\
\hline 2009 & 40 & 47 & 0 & 112 & $13.70 \%$ \\
\hline 2010 & 81 & 78 & 39 & 198 & $23.35 \%$ \\
\hline 2011 & 67 & 55 & 23 & 145 & $17.80 \%$ \\
\hline
\end{tabular}

Sumber :Divisi Umrah Haji Raka Tours 2011

Masih flutuaktifnya julah jamaah Raka Tours and travel menjadi salah satu akibat dari strategi perusahaan yang masih dirasakan belum tepat pada sasaran.

Berdasarkan beberapa masalah tersebut Raka Tours and Travel berupaya melaksanakan beberapa strategi dalam upaya menarik minat juga mempertahankan jumlah jamaah yang telah menggunakan paket umrah Raka Tours and Travel maupun para calon jamaah. Kegiatan promosi merupakan kegiatan yang penting, menurut Saladin (2003:123) mengemukakan promosi adalah suatu komunikasi informasi penjual dan pembeli yang bertujuan untuk merubah sikap dan tingkah laku pembeli, yang tadinya tidak mengenal menjadi mengenal sehingga menjadi pembeli dan tetap mengingat produk tersebut. Berdasarkan hal tersebut, Raka Tours and Travel melakukan upaya promosi untuk meningkatkan tingkat penjualan perusahaan melalui Direct Mail dan Telemarketing yang keduanya terdapat pada program Direct Marketing.

Diret marketing salah satu alat promosi yang dinilai cukup efektif, hal ini dikarenakan adanya kedekatan secara lebih antara perusahaan dengan target pasar yang dapat memungkinkan terjadinya komunikasi dua arah, selain itu komunikasi yang dilakukan secara langsung dapat memberikan kesempatan yang lebih besar untuk dapat memperoleh respon maupun transaksi.

Telemarketing merupakan bentuk penawaran lanjutan yang dilakukan setelah adanya respon yang berasal dari segmen pasar yang ditargetkan melalui telepon. Dalam penawaran ini, pihak perusahaan akan lebih leluasa memberikan penawaran secara langsung dan lebih dapat melakukan variasivariasi penawaran yang dapat menarik minat target jamaah, telemarketing juga dilakukan agar para calon jamaah maupun jamah mau menggunakan paket umrah Raka kembali.

Kegiatan promosi direct marketing melalui direct mail dan telemarketing merupakan sarana yang penting untuk dilaksanakan Raka Tours and Travel sebagai salah satu media untuk dapat meningkatkan jumlah pembelian paket umrah dengan tetap menjaga hubungan dengan jamaah dengan target segmen pasar yang jelas dan dalam pelaksanaanya dapat terukur dengan baik.

Dengan adanya kegiatan promosi ini, pihak perusahaan memiliki tujuan guna meningkatkan keputusan pembelian dari jamaah sekaligus tetap menjaga hubungan dengan jamaah tersebut.

Berdasarkan latar belakang di atas, maka perlu dilakukan suatu penelitian dengan judul "Pengaruh Direct Mail dan Telemarketing Terhadap Keputusan Pembelian Paket Umrah Raka Tours and Travel (Survey Terhadap Pengguna Paket Umrah Raka Tours and Travel)

\section{KERANGKA PEMIKIRAN}

\subsection{Kerangka Pemikiran}

Pariwisata merupakan ilmu yang hadir dikarenakan perkembangan kebutuhan manusia dan juga merupakan disiplin ilmu yang tidak bisa berdiri sendiri, itu artinya pariwisata menyangkut hajat hidup orang banyak juga menyangkut berbagai industri yang terkait di dalamnya. Pariwisata sendiri memiliki pengertian yang tercantum dalam Undang-undang no. 10 tahun 2009 yaitu berbagai macam kegiatan wisata dan didukung berbagai fasilitas serta layanan yang disediakan oleh masyarakat, pengusaha, Pemerintah dan Pemerintah Daerah. Dalam pengertian tersebut terdapat berbagai fasilitas serta layanan yang tersedia, yang dalam hal ini dapat diartikan sebagai usaha pariwisata yang saat ini semakin marak berdiri, salah satunya adalah jasa perjalanan wisata. 
Jasa perjalanan pariwisata merupakan salah satu bagian penting dalam pariwisata.Adanya lembaga yang mengatur perjalanan dan lebih memudahkan wisatawan dalam melakukan kegiatan wisata tentu saja menjadi aset penting yang dapat mendatangkan keuntungan kedua belah pihak.Biro perjalanan wisata merupakan bagian dari industri pariwisata yang keberadaanya merupakan salah satu bagian penting.Dan tentu saja biro perjalanan wisata ini memiliki bidang promosi yang di dalamnya terdapat strategi-strategi marketing yang membantu biro perjalanan wisata dalam menjawab perkembangan konsumen dari berbagai aspek.

Saat ini marketing telah menjadi bidang dengan perkembangan yang mencengangkan setiap tahunnya.Marketing kini bukan hanya berbicara mengenai bagaimana menjual barang atau jasa, namun bagaimana membina hubungan baik dengan konsumen sehinggga hubungan antara penjual dan pembeli dapat terbina dan dapat memberikan nilai positif baik bagi penjual maupun pembeli, menciptakan nilai bagi pelanggan dan membangun hubungan yang kuat dengan tujuan menangkap nilai dari pelanggan sebagai imbalannya (Kotler dan Amstrong $2012: 29$ ).

Marketing merupakan konsep yang didalamnya terdapat alat-alat pemasaran guna mencapai target perusahaan, dimana terdapatnya product sebagai kombinasi dari barang dan jasa yang ditawarkan perusahaan, price yang merupakan banyaknya biaya yang dikeluarkan oleh pelanggan untuk memperoleh produk,aktivitas perusahaan yang membuat produk yang terdapat dalam place, serta promotion yang merupakan aktivitas pengkomunikasian produk dan mengajak pelanggan untuk membelinya, dan seiring dengan perkembangan pemasaran itu sendiri, alat pemasaran ini semakin baik dengan ditambahkannya people, programs, performances, dan process (Kotler dan Keller 2012 : 47).

Promosi menjadi salah satu elemen dalam bauran pemasaran yang dapat menguntungkan perusahaan, khususnya perusahaan jasa. Dengan adanya promosi, permintaan konsumen dapat ikut terdorong sehingga dapat menaikan produksi dari barang dan jasa yang ada pada perusahaan. Promosi menjadi salah saru elemen penting, karena di dalamnya terdapat fase-fase, yaitu fase memberikan informasi, fase mempengaruhi hingga membujuk pelanggan maupun calon pelanggan hinggga mempengaruhi keputusan pembeliannya. Seluruh fase ini sangat berdaya guna dalam memenuhi target pasar.

Bauran pemasaran atau promotion mix merupakan cara yang dilaksanakan guna mencapai sasaran perusahaan, dimana di dalamnya terdapat elemen promosi. Promosi merupakan penentu keberhasilan program pemasaran. Apapun keunggulan suatu produk, bila konsumen tidak pernah mendengarnya, mengetahuinya dan betapa barang tersebut berguna bagi mereka, tetap saja konsumen tidak akan pernah membelinya.

Dengan berbagai perkembangan yang ada, bauran pemasaran memiliki 6 elemen yang menjadi kunci dalam rangka pemenuhan target pasar (Lovelock 2009 : 178), yaitu Advertising yang menjadi bentuk promosi favorit di berbagai perusahaan, dimana di dalamnya tentu saja harus bersifat efektif, Direct marketing yang merupakan sistem pemasaran bersifat interaktif, yang memanfaatkan satu dari beberapa media iklan untuk menimbulkan respon yang dapat diukur, Sales Promotion merupakan pengoptimalan berbagai insentif guna merangsang pembelian produk dengan segera, komunikasi tatap muka secara langsung melalui Personal selling, komunikasi secara menyeluruh dari suatu perusahaan dalam Public relations, dan terakhir Trade show atau yang lebih dikenal dengan publisitas yang merupakan bentuk penyebaran ide, barang, dan jasa secara non personal dimana organisasi yang diuntungkan tidak membayar untuk itu.

Direct Marketing merupakan salah satu elemen penting dalam pemasaran. Direct marketing memiliki penargetan merk, dimana setiap komunikasi di dalamnya merupakan komunikasi yang telah terukur, dengan tujuan menumbuhkan keinginan sehingga menguntungkan perusahaan (Anthony G Bennet 2010:253). Hubungan yang baik dengan pelanggan membuat direct marketing menjadi elemen yang efektif dalam menambah jumlah pelanggan juga mempertahankannya, selain itu elemen ini juga dapat dijadikan sebagai upaya untuk mengubah perilaku pelanggan, selain itu fokus dari direct marketing ini lebih terarah karena berfokus kepada individu atau segment audienns. Dalam meciptakan hubungan yang erat dengan pelanggan, diperlukan adanya data yang akurat dan terukur, maka direct marketing menajadi 
element yang paling cocok digunakan dalam perusahaan dengan pengaturan data yang baik untuk melakukan kegiatan promosi secara terarah. Berdasarkan prinsip-prinsip tersebut lah maka direct marketing telah menjadi program promosi yang sudah hampir 2 tahun ini dilaksanakan Raka Tours and Travel.

Direct marketing digunakan guna mempromosikan paket umrah yang dimiliki oleh Raka Tours. Menurut Roddy Mulin (2009:12), direct marketing memiliki banyak keunggulan, yaitu tentu saja dapat memberikan keuntungan karena adanya target pelanggan yang jelas, direct marketing juga dapat mempersonalisasikan pesan terhadap pelanggan. Direct marketing juga lebih efektif dalam membangun hubungan dengan pelanggan, memberikan fleksibilitas kreatif dalam setiap media, terakhir direct marketing memberikan hasil yang paling akurat. Direct marketing dapat menjadi strategi efektif dalam penekanan biaya yang dikeluarkan perusahaan sehingga memiliki nilai yang seimbang bahkan lebih dengan hasil yang didapatkan.

Dalam melaksanakan direct marketing ini , ada beberapa saluran atau dimensi yang dapat dilaksanakan guna mendukung pelaksanaan program promosi tersebut. Menurut Anthony D Bennet (2010:258), dimensi direct marketing adalah direct mail, e-mail, direct print,telemarketing, online and mobile media dan social media. Dari beberapa dimensi tersebut, direct mail dan telemarketing yang secara langsung digunakan oleh Raka Tours and Travel dalam upaya mempromosikan paket umrah dalam upaya meningkatkan keputusan pembelian.

Direct mail merupakan setiap bahan cetak, baik itu surat, kartu pos maupun semacam catalog yang dikirim melalui alamat email pelanggan. Ini dapat berupa pernyataan, pengingat maupun tagihan.

Telemarketing, penjualan melalui telepon yang merupakan salah satu cara paling efektif untuk berbicara dengan pelanggan secara one to one.

Hasil akhir dari program direct marketing melalui direct mail dan telemarketing ini adalah terciptanya pembelian atas barang dan jasa yang ditawarkan, yang dalam penelitian ini adalah paket umrah Raka Tours and Travel. Oleh karena itu, perusahaan harus dapat mengetahui bagaimana perilaku pembelian dari konsumen yang dijadikan sasarannya.

Proses bagaimana seseorang memutuskan untuk melakukan pembelian dipengaruhi oleh budaya, sosial, pribadi juga psikologi (Kotler dan Amstrong dalam Ratih Hurriyati 2010:94), faktor - faktor ini dapat dikategorikan menjadi faktor yang dapat dikendalikan dan tidak dapat dikendalikan oleh pemasar. Keputusan pembelian merupakan proses, dimana konsumen melihat berbagai alternatif yang ada, mempertimbangkan bahkan membandingkan. Pemilihan dari dua atau lebih alternatif pilihan keputusan pembelian (Schiffman, Kanuk 2004:574) ini juga merupakan proses yang terdiri 5 tahapan yaitu pengenalan kebutuhan, pencarian informasi, pengevaluasian alternatif, keputusan pembelian dan prilaku setelah pembelian (Kotler dan Amstrong 2003:224). Setiap perusahaan harus secara teratur menganalisis keputusan pembelian konsumen, karena seiring berjalanya waktu hal tersebut pun ikut berubah dan mengalami perkembangan. Dimana adanya pemilihan produk juga jasa, pemilihan waktu pembelian, berapa banyak jumlah pembeliannya serta metode pembayaran apa yang digunakan.

Keputusan pembelian dalam paket umrah Raka Tours and Travel dapat dilihat dari bagaimana upaya promosi yang dilaksanakan perusahaan melalui program promosi direct marketing yang didalamnya terdapat direct mail dan telemarketing.

\subsection{Hipotesis}

Berdasarkan teori-teori yang telah dikemukakan, maka penulis mengajukan hipotesis yang akan dibuktikan melalui penelitian. Menurut Sugiyono (2008:39), hipotesis adalah jawaban sementara terhadap permasalahan, yaitu berkaitan dengan variabel materi. Sehingga dapat dikatakan bahwa hipotesis merupakan rumusan permasalahan penelitian yang belum dijawab secara empiris.

Peneliti dalam menyusun hipotesis didukung oleh beberapa premis yang menyatakan pengaruh direct marketing terhadap keputusan pembelian yaitu sebagai berikut:

1. Anthony G Bennet, RAAP (2010:254)

Dampak dari komunikasi direct marketing yaitu dimana pemasar dapat merespon lebih cepat keinginan konsumen dan berpengaruh positif dalam perubahan perilaku pembelian konsumen

2. Direct Marketing Assosiation dalam Lambin ( 2007:1)

Direct marketing adalah satu sistem interaktif yang menggunakan satu atau lebih media 
periklanan untuk mempengaruhi satu respon terukur dan transaksi di lokasi manapun.

3. Hudson (2008:312)

Direct marketing adalah sistem pemasaran yang dikendalikan penuh oleh pemasar, untuk mengembangkan produk, mempromosikan dan mendistribusikan langsung produknya pada konsumen akhir dengan menggunakan beberapa pilihan media dan menerima pemesanan langsung dari pelanggan

4. Naik dan Piersma (2001:1).

Dampak dari komunikasi dalam model respon direct marketing lebih baik daripada media lain karena dapat memahami perannya dalam mempengaruhi perilaku konsumen.

Berdasarkan premis di atas maka hipotesis dalam penelitian ini adalah terdapat pengaruh positif antara Direct Mail dan Telemarketing terhadap keputusan pembelian paket umrah Raka Tours and Travel.

\section{METODE PENELITIAN}

\subsection{Objek Penelitian}

Penelitian ini menganalisis mengenai Direct Mail dan Telemarketing terhadap keputusan pembelian paket umrah Raka Tours and Travel. Adapun yang menjadi variabel bebas (independent variable) adalah Direct Marketing atau variabel X yang terdiri dari Direct mail $\left(\mathrm{X}_{1}\right)$ dan Telemarketing $\left(\mathrm{X}_{2}\right)$. Variabel terikat (dependent variable) atau variable $\mathrm{Y}$ adalah keputusan pembelian yang terdiri dari Pilihan Produk dan Jasa, Pilihan Waktu Pembelian, Jumlah Pembelian dan Metode Pembayaran. Unit analisis dari penelitian ini adalah pengguna paket umrah Raka Tours and Travel.

\subsection{Metode Penelitian}

Penelitian ini menggunakan jenis penelitian deskriptif dan verifikatif dilihat dari variabel-variabel yang diteliti . Menurut Sugiyono (2008:11), penelitian deskriptif adalah penelitian yang dilakukan untuk mengetahui nilai variabel mandiri, baik secara satu variabel atau lebih (independent) tanpa membuat perbandingan, atau menghubungkan dengan variabel yang lain. Penelitian deskriptif disini bertujuan untuk memperoleh deskripsi tentang gambaran mengenai direct marketing yang terdiri dari direct mail dan telemarketing terhadap keputusan pembelian pembelian paket umrah Raka Tours and Travel. Adapun penelitian verifikatif dimana penelitian verifikatif menurut Suharsimi Arikunto (2009:8) merupakan "Penelitian yang pada dasarnya ingin menguji kebenaran melalui pengumpulan data di dalam lapangan" pada dasarnya ingin menguji kebenaran dari suatu hipotesis yang dilaksanakan melalui pengumpulan data di lapangan. Dalam penelitian ini, penelitian verifikatif bertujuan untuk mengetahui pengaruh direct mail dan telemarketing terhadap keputusan pembelian pembelian paket umrah Raka Tours and Travel. Berdasarkan variabel yang diteliti maka jenis penelitian ini merupakan penelitian deskriptif dan verifikatif, dilaksanakan melalui pengumpulan data di lapangan, maka metode penelitian yang digunakan adalah metode descriptive survey dan metode explanatory survey. Menurut Zulganef (2008:11) descriptive survey adalah penelitian yang bertujuan menelaah kausalitas antar variabel yang menjelaskan suatu fenomena tertentu. Sedangkan menurut Zulganef (2008:11) explanatory survey adalah penelitian yang bertujuan menggambarkan suatu kondisi atau fenomena tertentu, tidak memilah-milah atau mencari faktor-faktor atau variabel tertentu. Dalam penelitian yang menggunakan metode ini, informasi dari sebagian populasi dikumpulkan langsung ditempat secara empirik dengan tujuan untuk mengetahui pendapat dari sebagian populasi terhadap objek yang sedang diteliti.

Metode pengembangan yang dipergunakan adalah cross-sectional method. Menurut Husein Umar (2009:42), cross sectional method yaitu metode penelitian dengan cara meneliti suatu fenomena tertentu dalam satu kurun waktu saja.

\subsection{Operasionalisasi Variabel}

Adapun variabel yang diteliti dalam penelitian ini adalah direct marketing sebagai variable bebas $(\mathrm{X})$ dengan sub variable Direct Mail $\left(\mathrm{X}_{1}\right)$ dan Telemarketing $\left(\mathrm{X}_{2}\right)$ serta keputusan pembelian paket umrah sebagai variabel terikat (Y). Sedangkan keputusan pembelian terdiri dari pilihan produk dan jasa, pilihan waktu pembelian, jumlah pembelian dan metode pembayaran. 


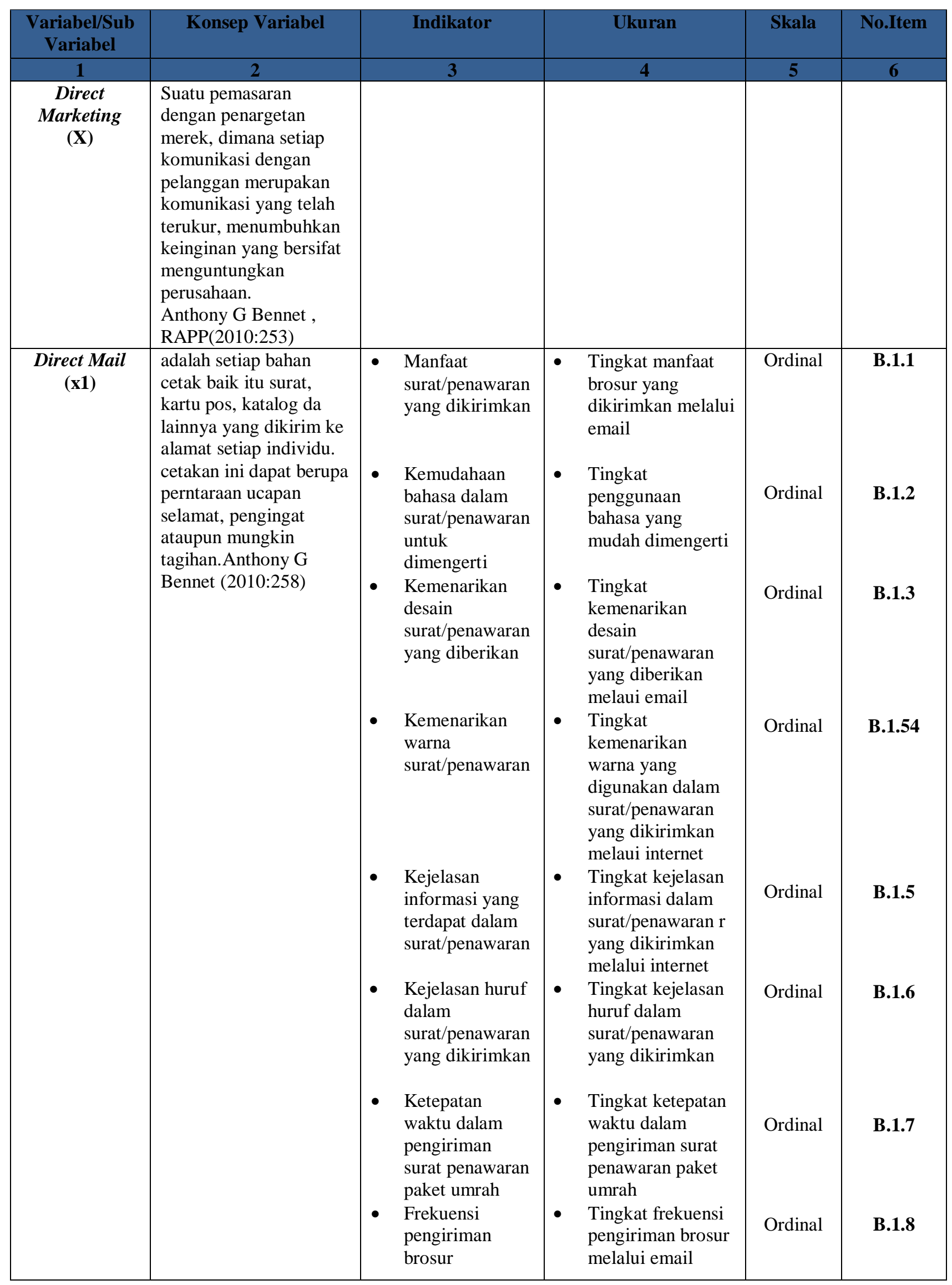




\begin{tabular}{|c|c|c|c|c|c|}
\hline $\begin{array}{c}\text { Variabel/Sub } \\
\text { Variabel }\end{array}$ & Konsep Variabel & Indikator & Ukuran & Skala & No.Item \\
\hline 1 & 2 & 3 & 4 & 5 & 6 \\
\hline \multirow[t]{6}{*}{$\begin{array}{l}\text { Telemarketing } \\
(x 2)\end{array}$} & \multirow[t]{6}{*}{$\begin{array}{l}\text { Penjualan melalui } \\
\text { telepon, merupakan } \\
\text { salah satu cara paling } \\
\text { efektif untuk berbicara } \\
\text { dengan pelanggan } \\
\text { secara one to one. } \\
\text { Anthony G Bennet } \\
(2010: 258)\end{array}$} & 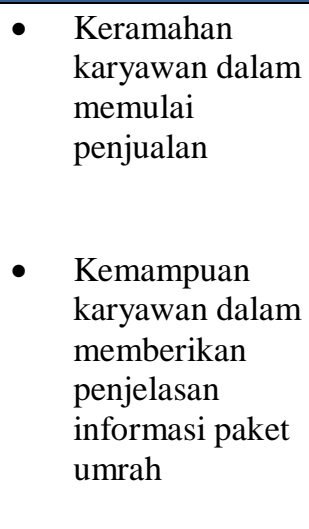 & $\begin{array}{ll}\text { - } & \text { Tingkat } \\
\text { keramahan } \\
\text { karyawan dalam } \\
\text { membuka } \\
\text { penjualan } \\
\text { - } \\
\text { Tingkat } \\
\text { kemampuan } \\
\text { karyawan dalam } \\
\text { memberikan } \\
\text { penjelasan } \\
\text { informasi paket } \\
\text { umrah }\end{array}$ & Ordinal & B.II.10 \\
\hline & & $\begin{array}{l}\text { - Kelancaran } \\
\text { karyawan dalam } \\
\text { memberikan } \\
\text { penjelasan }\end{array}$ & $\begin{array}{l}\text { Tingkat } \\
\text { kelancaran } \\
\text { karyawan dalam } \\
\text { memberikan } \\
\text { penjelasan }\end{array}$ & Ordinal & B.II.11 \\
\hline & & $\begin{array}{l}\text { Pengetahuan } \\
\text { yang dimiliki } \\
\text { karyawan } \\
\text { mengenai } \\
\text { produk }\end{array}$ & $\begin{array}{ll}\text { - } & \text { Tingkat } \\
\text { pengetahuan } \\
\text { karyawan dalam } \\
\text { menjelaskan paket } \\
\text { umrah }\end{array}$ & Ordinal & B.II.12 \\
\hline & & $\begin{array}{l}\text { - Kemampuan } \\
\text { karyawan dalam } \\
\text { menjelaskan } \\
\text { paket }\end{array}$ & $\begin{array}{l}\text { Tingkat } \\
\text { kemampuan } \\
\text { karyawan dalam } \\
\text { menjelaskan } \\
\text { keunggulan paket }\end{array}$ & Ordinal & B.II.13 \\
\hline & & $\begin{array}{l}\text { - Kemampuan } \\
\text { karyawan dalam } \\
\text { pemberian } \\
\text { solusi }\end{array}$ & $\begin{array}{ll}\text { - } & \text { Tingkat } \\
\text { kemampuan } \\
\text { karyawan dalam } \\
\text { memberikan solusi }\end{array}$ & Ordinal & B.II.14 \\
\hline & & $\begin{array}{ll}\text { - } & \text { Ketepatan } \\
\text { pemilihan } \\
\text { waktu dalam } \\
\text { menelepon }\end{array}$ & $\begin{array}{l}\text { - Tingkat ketepatan } \\
\text { waktu dalam } \\
\text { menelepon }\end{array}$ & Ordinal & B.II.15 \\
\hline
\end{tabular}




\begin{tabular}{|c|c|c|c|c|c|}
\hline $\begin{array}{l}\text { Keputusan } \\
\text { Pembelian (y) }\end{array}$ & \begin{tabular}{|l|} 
Perilaku pembelian \\
bisnis dari organisasi \\
yang membeli barang \\
atau layanan yang \\
digunakan dalam \\
produksi produk atau \\
jasa layanan lain atau \\
untuk tujuan dijual \\
kembali atau \\
menyewakannya \\
kembali ke pihak lain \\
untuk mendapatkan laba \\
(Kotler dan Amstrong, \\
2008:196) \\
\end{tabular} & & & & \\
\hline $\begin{array}{l}\text { Pilihan produk } \\
\text { dan Jasa }\end{array}$ & & $\begin{array}{l}\text { - Kesesuaian paket } \\
\text { dengan kebutuan } \\
\text { jamaah } \\
\text { - Kelebihan paket } \\
\text { dibanding paket } \\
\text { travel lain } \\
\text { - Variasi paket } \\
\text { yang ditawarkan }\end{array}$ & $\begin{array}{ll}\text { - } & \text { Tingkat } \\
\text { kesesuaian paket } \\
\text { umrah dengan } \\
\text { kebutuhan calon } \\
\text { jamaah } \\
\text { - Tingkat } \\
\text { keunikan/kelebiha } \\
\text { n paket umrah } \\
\text { dibanding paket } \\
\text { lain } \\
\text { - Tingkat } \\
\text { keragaman jenis } \\
\text { paket yang } \\
\text { dimiliki }\end{array}$ & $\begin{array}{l}\text { Ordinal } \\
\text { Ordinal }\end{array}$ & C.I.3 \\
\hline $\begin{array}{l}\text { Pilihan Waktu } \\
\text { Pembelian }\end{array}$ & & $\begin{array}{ll}\text { - } & \text { Keseuaian paket } \\
\text { umrah dengan } \\
\text { keinginan calon } \\
\text { jamaah } \\
\text { - } \\
\text { Kesesuaian } \\
\text { waktu umrah } \\
\text { dengan } \\
\text { keinginan tamu }\end{array}$ & $\begin{array}{ll} & \text { Tingkat } \\
\text { kesesuaian paket } \\
\text { umrah dengan } \\
\text { keinginan calon } \\
\text { jamaah } \\
\text { - Kesesuaian waktu } \\
\text { umrah dengan } \\
\text { keinginan tamu }\end{array}$ & $\begin{array}{l}\text { Ordinal } \\
\text { Ordinal }\end{array}$ & C.II.5 \\
\hline $\begin{array}{c}\text { Jumlah } \\
\text { Pembelian }\end{array}$ & & $\begin{array}{ll}\text { Frekuensi } \\
\text { menggunakan } \\
\text { paket umrah } \\
\text { dalam satu } \\
\text { tahun } \\
\text { - } \\
\text { Frekuensi } \\
\text { menggunakan } \\
\text { paket umrah } \\
\text { dalam musim } \\
\text { haji }\end{array}$ & 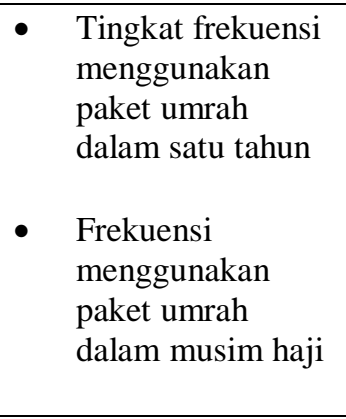 & $\begin{array}{l}\text { Ordinal } \\
\text { Ordinal }\end{array}$ & C.1II.6 \\
\hline $\begin{array}{c}\text { Metode } \\
\text { Pembayaran }\end{array}$ & ngolahan Data 2012 & $\begin{array}{ll} & \text { Kemudahan } \\
\text { melakukan } \\
\text { pembayaran } \\
\text { secara tunai } \\
\text { Kemudahan } \\
\text { pembayaran } \\
\text { secara non tunai }\end{array}$ & 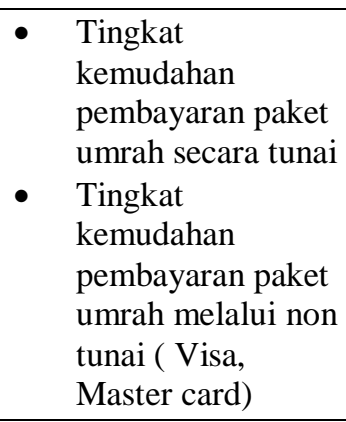 & Ordinal & C.1V.8 \\
\hline
\end{tabular}




\subsection{Populasi, Sample dan Teknik Sampling}

Menurut Sugiyono (2010:115) mendefinisikan populasi sebagai berikut, "Populasi adalah wilayah generalisasi yang terdiri atas : objek/subjek yang mempunyai kualitas dan karakteristik tertentu yang ditetapkan oleh peneliti untuk dipelajari dan kemudian ditarik Mengenai jumlah dari bendabenda tersebut tetapi juga mencakup karakteristik yang dimiliki objek dan subjek tersebut.

Berdasarkan pengertian populasi tersebut maka populasi dalam penelitian ini adalah pengguna paket umrah Raka Tours and Travel. Adapun populasi pengguna paket Raka Tours and Travel pada tahun 2011 yaitu sebanyak 145 orang.

Menurut Nazir (2007:73) mengemukakan bahwa: "sampel adalah bagian dari populasi". Sedangkan menurut Sugiyono (2010:116), "Sampel adalah bagian dari jumlah dan karakteristik yang dimiliki oleh populasi tersebut ", selain itu agar diperoleh sample yang representatif dari populasi maka setiap subjek diupayakan untuk memiliki peluang yang sama untuk menjadi sampel Malhotra (2005:364).

Berdasarkan pada pengertian-pengertian diatas, maka sampel yang digunakan dalam penelitian ini adalah sebagian dari populasi penelitian yaitu pengguna paket umrah Raka Tours and Travel,dimana terdiri dari 3 (tiga) kantor perwakilan Raka Tours and Travel sendiri yaitu di Bandung sebagai kantor pusat, Bukit Tinggi dan Lampung.

Untuk mengukur sampel, peneliti menggunakan rumus iterasi, yakni ukuran sample yang merupakan perbandingan dari ukuran populasi dengan prosentase kelonggaran ketidaktelitian, karena dalam pengambilan sample masih dapat ditolerir atau diinginkan.

Dalam pengambilan sampel ini peneliti menggunakan taraf kesalahan 5\%. Berdasarkan hasil perhitungan menggunakan rumus iterasi, diperoleh jumlah sampel minimal sebesar 101 jamaah, tapi untuk jaminan baiknya sampel selalu ditambah sedikit dari jumlah matematikanya. Berdasarkan ukuran sampel (n) minimal, maka dalam penelitian ini ditetapkan ukuran sampel sebanyak 110 agar lebih proposional. rumus Iterasi adalah sebagai berikut :

$$
\mathrm{n}_{1}=\frac{\left(\mathrm{Z}_{1-\alpha}+\mathrm{Z}_{1-\beta}\right)^{2}}{\left(\mathrm{U}_{\mathrm{p}}^{\prime}\right)^{2}}+3 \text { di mana: } \mathrm{U}_{\mathrm{p}}^{\prime}=\frac{1}{2} \operatorname{Ln}\left(\frac{1+\rho}{1-\rho}\right)
$$

Penelitian ini menggunakan teknik systematic random sampling, dikarenakan populasinya yang sejenis (homogen) dan dapat dilakukan secara acak tanpa memperhatikan strata yang ada dalam populasi tersebut. Metode tersebut dipilih agar peneliti dapat dengan mudah menentukan objek untuk dijadikan sample dengan tetap menerapkan aturan yang mana setiap elemen dalam populasi memiliki peluang yang sama.

\subsection{Teknik Pengumpulan Data}

Pengumpulan data yang penulis gunakan dalam penelitian ini adalah :
a. Wawancara
b. Kuesioner
c. Studi literature

\subsection{Pengujian Hipotesis}

Teknik analisis data yang digunakan dalam penelitian ini adalah regresi linier berganda (multiple linier regression). Analisis regersi linier berganda adalah suatu alat analisis peramalan nilai pengaruh dua atau lebih variabel bebas (X) terhadap variabel terkait $(\mathrm{Y})$ untuk membuktikan ada atau tidaknya hubungan kausal antara dua variabel bebas atau lebih.

Teknik analisis regresi yang digunakan dalam penelitian ini adalah regresi liner berganda. Menurut Asep Hermawan (2005:220) regresi linier berganda merupakan suatu model statistik yang sesuai jika masalah penelitian mencakup satu variabel terkait (dependent) yang berskala pengukuran metrik (internal atau rasio), yang diduga dapat diorediksikan oleh variabel-variabel independent yang berskala metrik (interval atau rasio).

Analisis regresi digunakan bila penelitian bermaksud ingin mengetahui kondisi diwaktu yang akan datang dengan suatu dasar keadaan sekarang atau ingin melihat kondisi waktu lalu dengan dasar keadaan dimana sifat ini merupakan prediksi atau perkiraan (Irianto, 2006:156). Arti kata prediksi bukanlah merupakan hal yang pasti tetapi merupakan suatu keadaan yang mendekati kebenaran. Dampak dari 
penggunaan analisis regresi dapat digunakan untuk memutuskan apakah naik dan menurunnya variabel dependent dapat dilakukan melalui menaik dan menurunnya keadaan variabel independent atau meningkatkan keadaan variabel dependen dapat dilakukan dengan meningkatkan variabel independen sebaliknya (Sugiyono, 2008:204).

Berdasarkan tujuan penelitian ini, maka variabel yang dianalisis adalah variabel independen yaitu direct marketing yang terdiri dari direct selling, direct mail, dan telemarketing. Sedangkan variabel dependen adalah keputusan menggunakan jasa (Y). Untuk bisa membuat ramalan melalui regresi, maka data setiap variabel harus tersedia. Persamaan regresi berganda dua variable bebas dirumuskan sebagai berikut.

$$
Y=a+b_{1} X_{1}+b_{2} X_{2}
$$

Sumber : Sugiyono (2010:289)

Keterangan:

$\mathrm{Y}=$ Subjek / nilai dalam variabel dependen yang diprediksikan.

$\mathrm{a}=\quad$ Nilai $\mathrm{Y}$ bila $\mathrm{X}=0$

$\mathrm{b}=\quad$ Angka arah atau koefisien regresi, yang menunjukkan angka peningkatan ataupun penurunan variabel independen yang didasarkan pada variabel independen. Bila b (+) maka naik, dan bila (-) maka terjadi penurunan.

$X=\quad$ Subjek pada variabel independen yang mempunyai nilai tertentu. $\mathrm{X}_{1}=$ direct mail, $\mathrm{X}_{2}=$ telemarketing

Menurut Sugiyono (2008:277) analisis regresi berganda digunakan bila penelitian bermaksud meramalkan bagaimana keadaan (naik turunnya) variabel dependen (kriterium), bila dua atau lebih variabel independen sebagai faktor predikator dimanipulasi (dinaik-turunkan nilainya). Analisis regresi berganda akan dilakukan bila jumlah variabel independen minimalnya dua atau lebih.

Menerjemahkan ke dalam beberapa sub hipotesis yang menyatakan pengaruh sub variabel independen yang paling dominan terhadap variabel dependen, lebih jelasnya dapat dilihat pada Gambar berikut

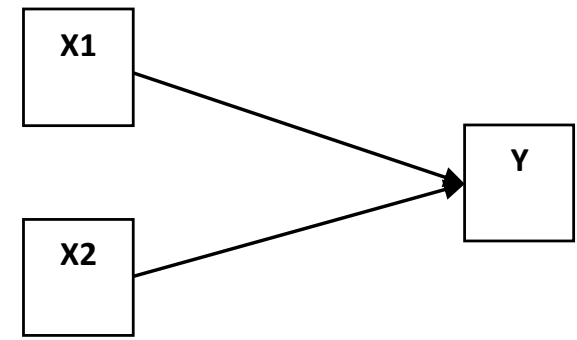

GAMBAR REGRESI BERGANDA

Keterangan :

$\mathrm{X}_{1}=$ Direct Mail

$\mathrm{X}_{2} \quad=$ Telemarketing

$\mathrm{Y} \quad=$ Keputusan Pembelian

Kriteria pengambilan keputusan untuk hipótesis yang diajukan adalah:

Jika $t_{\text {hitung }}>t_{\text {tabel }}$ maka $\mathrm{H}_{\mathrm{o}}$ ditolak dan $\mathrm{H}_{\mathrm{a}}$ diterima

Jika $t_{\text {hitung }}<\mathrm{t}_{\text {tabel }}$ maka $\mathrm{H}_{\mathrm{o}}$ diterima dan $\mathrm{H}_{\mathrm{a}}$ ditolak

Hipótesis yang akan diuji dalam rangka pengambilan keputusan penerimaan atau penolakan hipotesis dapat di tulis sebagai berikut.

Jika $t_{\text {hitung }}>t_{\text {tabel }}$ maka $H_{o}$ ditolak dan $\mathrm{H}_{\mathrm{a}}$ diterima :

Ho : bi $=0$; Tidak terdapat pengaruh Direct Mail terhadap Keputusan Pembelian Paket Umrah raka Tours and Travel

Hi : bi $\neq 0$; Terdapat pengaruh Direct Mail terhadap Keputusan Pembelian Paket Umrah raka Tours and Travel

Jika $t_{\text {hitung }}<t_{\text {tabel, }}$ maka Ho ditolak dan Hi diterima

Ho : bi $=0$; Tidak terdapat pengaruh Telemarketing terhadap Keputusan Pembelian Paket Umrah raka Tours and Travel

Hi :bi $\neq 0$; Terdapat pengaruh Telemarketing terhadap Keputusan Pembelian Paket Umrah raka Tours and Travel

Jika $t_{\text {hitung }}<t_{\text {tabel, }}$ maka Ho ditolak dan Hi diterima

\section{a. Sub Hipotesis}

Jika $\mathrm{t}$ hitung $>\mathrm{t}$ tabel, maka $\mathrm{H}_{\mathrm{o}}$ ditolak maka $\mathrm{H}_{\mathrm{a}}$ diterima

$\mathrm{H}_{\mathrm{o}}=0$, tidak terdapat pengaruh yang signifikan direct mail di Raka Tours and Travel terhadap keputusan pembelian paket umrah.

$\mathrm{H}_{\mathrm{a}} \neq 0$, terdapat pengaruh yang signifikan direct mail di Raka Tours and Travel terhadap keputusan pembelian paket umrah. 
Jika $\mathrm{t}_{\text {hitung }}>\mathrm{t}_{\text {tabel}}$, maka $\mathrm{H}_{\mathrm{o}}$ ditolak maka $\mathrm{H}_{\mathrm{a}}$ diterima

$\mathrm{H}_{\mathrm{o}}=0$, tidak terdapat pengaruh yang signifikan telemarketing di Raka Tours and Travel terhadap keputusan pembelian paket umrah.

$\mathrm{H}_{\mathrm{a}} \neq 0$, terdapat pengaruh signifikan telemarketing di Raka Tours and Travel terhadap keputusan pembelian paket umrah.

\section{HASIL PENELITIAN DAN PEMBAHASAN}

4.1 Tanggapan Responden (Jamaah) Terhadap Direct Marketing dan Telemarketing

Berikut merupakan sub total skor dari kedua sub variable sehingga dapat dilihat subvariable yang memiliki tanggapan baik dari jamah yang telah menggunakan paket umrah Raka Tours and Travel. Perhitungan skor variable dapat dilihat pada Tabel berikut.

\section{TABEL 4.1 REKAPITULASI TANGGAPAN RESPONDEN TERHADAP DIRECT MAIL DAN TELEMARKETING}

\begin{tabular}{|c|c|c|c|c|}
\hline No. & Sub Variabel & $\begin{array}{c}\text { Total } \\
\text { skor }\end{array}$ & $\begin{array}{c}\text { Skor } \\
\text { Rata- } \\
\text { rata }\end{array}$ & $\%$ \\
\hline 1 & Direct Mail & 2595 & 324 & 64.8 \\
\hline 2 & Telemarketing & 1705 & 341 & 35.2 \\
\hline & TOTAL & $\mathbf{4 3 0 0}$ & $\mathbf{4 3 1 . 5}$ & $\mathbf{1 0 0}$ \\
\hline
\end{tabular}

Sumber: Pengolahan Data 2012

Berdasarkan Tabel $4.20 \quad$ dari pelaksanaan direct marketing yang terdiri dari direct mail dan telemarketing, dimana direct mail mendapatkan penilaian paling tinggi, yaitu sebesar $64,8 \%$. Hal ini dikarenakan desain yang telah dibuat oleh pihak perusahaan telah cukup memenuhi rasa keingintahuan dari calon jamaah, selain mudah diaplikasikan, tampilan dari direct mail cukup mendapatkan perhatian lebih dari calon jamaah sehingga respon yang selanjutnya diberikan oleh jamaah merupakan respon positif, selain itu direct mail merupakan salah satu dasar dari direct marketing itu sendiri dan sangat menentukan prilaku pembelian jamaah selanjutnya.
Sedangkan penilaian terendah ada pada telemarketing yaitu sebesar $35.2 \%$ hal ini dikarenakan masih diperlukananya managemen atau pengaturan yang baik dalam melaksanakan telemarketing, selain itu kemampuan tenaga penjual dalam mengkomunikasikan paket melalui telepon tidak sama.Dimana sikap karyawan dalam menelepon, nada suara yang digunakan, waktu penawaran serta informasi yang diberikan tidak sesuai dengan apa yang jamaah harapkan. Dalam hal ini kurang terlatihnya pihak perusahaan khususnya karyawan dalam berkomunikasi dengan jamaah melalui telepon sangat berpengaruh terhadap respon lanjutan yang diberikan oleh calon jamaah yakni keputusan dalam menggunakan paket umrah. Direct Mail dan Telemarketing merupakan satu kesatuan dalam Direct Marketing dimana keduanya harus bersinergi dalam mempengaruhi keputusan menggunakan paket umrah Raka Tours and Travel. Hal tersebut sesuai dengan pendapat Lambin dalam Direct Marketing Assosiation (2007:1) dimana Direct Marketing adalah satu sistem interaktif (dua arah) yang menggunakan satu atau lebih media periklanan untuk mempengaruhi satu respon terukur dan transaksi lokasi dimanapun.

\subsection{Tanggapan Responden Terhadap} Keputusan Pembelian Paket Umrah

Berikut tabel keputusan pembelian paket umrah.

\section{TABEL 4.2 REKAPITULASI \\ TANGGAPAN RESPONDEN} TERHADAP KEPUTUSAN PEMBELIAN PAKET UMRAH

\begin{tabular}{|c|c|c|c|c|}
\hline No. & Sub Variabel & $\begin{array}{l}\text { Total } \\
\text { skor }\end{array}$ & $\begin{array}{c}\text { Skor } \\
\text { Rata- } \\
\text { rata }\end{array}$ & $\%$ \\
\hline 1 & $\begin{array}{c}\text { Pilihan Produk } \\
\text { atau Jasa }\end{array}$ & 816 & 272 & 26.1 \\
\hline 2 & $\begin{array}{l}\text { Pilihan Waktu } \\
\text { dan Pembelian }\end{array}$ & 522 & 216 & 27.2 \\
\hline 3 & $\begin{array}{c}\text { Jumlah } \\
\text { Pembelian }\end{array}$ & 546 & 273 & 19.45 \\
\hline 4 & $\begin{array}{c}\text { Metode } \\
\text { Pembayaran }\end{array}$ & 650 & 325 & 27.1 \\
\hline \multicolumn{2}{|r|}{ TOTAL } & 2534 & 1086 & 100 \\
\hline
\end{tabular}

Sumber : Pengolahan Data 2012

Berdasarkan Tabel 4.25 penilaian terendah terdapat pada sub variabel jumlah pembelian yaitu sebesar $19.45 \%$ dikarenakan Raka Tours and Travel kurang dapat 
mempromosikan paketnya secara direct (langsung) dengan cukup baik, sehinga jamaah dapat melakukan promosi lanjutan secara tidak langsung dan membuat peluang membeli paket lebih banyak.

Sedangkan sub variable yang memiliki penilaian paling tinggi adalah pilihan waktu dan pembelian sebesar 27.2. Hal ini dikarenakan pada sub variable ini, mayoritas jamaah menyatakan tingkat kesesuaian baik itu dari kebutuhan jamaah dan kesesuaian waktu cukup sesuai. Keseluruhan dimensi pada keputusan pembelian ini berintegrasi dan membentuk sebuah perilaku, yakni perilaku pembelian. Hal tersebut sesuai dengan Kotler dan Keller (2008:240) yang mengemukakan salah satu model perilaku pembelian di mana di dalamnya memberikan gambaran bahwa pembelian bukan hanya merupakan satu tindakan, tetapi merupakan gabungan dari beberapa tindakan yang meliputi keputusan mengenai produk, bentuk, merek, jumlah, penjual dan waktu serta cara pembayarannya

\subsection{Pengaruh Direct Mail dan Telemarketing Terhadap Keputusan Pembelian Paket Umrah}

Berdasarkan pengujian hipotesis yang telah diajukan juga jenis data yang dikumpulkan, analisis data yang digunakan dalam penelitian ini adalah analisis regresi berganda untuk mengetahui seberapa besar pengaruh direct marketing dimana di dalamnya terdapat dimensi direct mail dan telemarketing terhadap keputusan pembelian. Hasil penelitian ini dapat terlihat dari hasil uji Asumsi Normalitas, Hasil uji Multikolinearitas,Hasil Uji Heterokedastisitas, hasil uji Koefisien Korelasi dan Koefisien Determinasi, melalui Pengujian Hipotesis dan Uji Signifikansi (Uji F), Uji Signifikansi Secara Parsial (Uji T) dan model persamaan regresi berganda berikut :

$\mathrm{Y}=\mathrm{a}+\mathrm{b} \times 1+\mathrm{b} \times 2$

Berdasarkan hasil pengolahan data pada Tabel 4.30 maka persamaan regresi bergandanya adalah :

$Y=9.318+0.403 \mathrm{x}_{1}+0.328 \mathrm{x}_{\text {? }}$

Persamaan tersebut a constant adalah 9.318, hal tersebut menyatakan bahwa direct mail dan telemarketing diabaikan maka nilai keputusan pembelian jamaah adalah 9.318. Apabila dinaikkan satu satuan, maka nilai keputusan pembelian akan naik sebesar 0.403 direct mail. Apabila telemarketing dinaikkan maka keputusan pembelian jamaah akan naik sebesar 0.328 , sedangkan sub variabel yang paling berpengaruh adalah direct mail karena memiliki nilai koefisien 0.403 . Hal ini sesuai dengan premis mengenai direct marketing yang terdiri dari direct mail dan telemarketing yang dingkapkan Anthony G Bennet, RAAP (2010:254) yaitu dampak dari komunikasi direct marketing yaitu dimana pemasar dapat merespon lebih cepat keinginan konsumen dan berpengaruh positif dalam perubahan perilaku pembelian konsumen.

\subsubsection{Implikasi Hasil Temuan Penelitian} 4.3.2 Temuan Penelitian Bersifat Empirik

Temuan dalam penelitian ini yang bersifat empirik adalah :

1. Direct Marketing merupakan salah satu cara untuk meningkatkan keputusan pembelian . Direct marketing secara simultan memiliki pengaruh yang positif terhadap keputusan pembelian paket umrah Raka Tours and Travel.

2. Direct marketing yang terdiri dari direct mail dan telemarketing merupakan hal yang sangat mempengaruhi direct marketing. Dari kedua dimensi yang diujian, direct mail merupakan dimensi dengan tingkat pengaruh yang paling tinggi. Hal ini dikarenakan jamaah ternyata cukup banyak mengetahui informasi paket umrah berdasarkan surat penawaran elektronik yang diberikan. Bahasa yang digunakan, desain yang menarik perhatian dan kejelasan informasi yang diberikan haruskah bersifat efektif dan efisien. Sehingga target calon jamaah yang sudah tersusun dalam database mampu dioptimalkan dengan sebaik mungkin. Namun tidak hanya itu, faktor lain seperti manfaat dari surat penawaran tersebut pun harus dirasakan oleh jamaah, seperti harga paket yang bersaing juga ittenerary yang menarik. Sedangkan dimensi lain yaitu telemarketing mendapatkan nilai yang lebih kecil dibandingkan direct mail, namun dimensi tersebut juga mempengaruhi secara positif terhadap keputusan pembelian paket umrah Raka Tours and Travel. Artinya kedua sub variabel atau dimensi dari direct marketing ini harus dioptimalisasi 
dengan sebaik mungkin sehingga mendapatkan nilai yang maksimal.

\subsubsection{Temuan Bersifat Teoritik}

1. Berdasarkan temuan penelitian yang bersifat teoritik penulis memperkuat konsep direct marketing yang dikemukakan oleh Anthony G Bennet, RAAP (2010 :254) "dampak dari komunikasi direct marketing yaitu dimana pemasar dapat merespon lebih cepat keinginan konsumen dan perpengaruh positif dalam perubahan perilaku pembelian konsumen". Hal ini dapat disimpulkan bahwa direct marketing dimana di dalamnya terdapat dimensi direct mail dan telemarketing memiliki pengaruh yang positif terhadap keputusan pembelian.

2. Berdasarkan temuan penelitian yang bersifat teoritik penulis memperkuat konsep direct marketing yang dikemukakan oleh Lambin (2007: 1), yaitu direct marketing adalah satu sistem interaktif yang menggunakan satu atau lebih media periklanan untuk mempengaruhi satu respon terukur dan transaksi di lokasi manapun. Hal ini dapat disimpulkan bahwa direct mail dan telemarketing merupakan media periklanan yang mampu mempengaruhi respon juga transaksi.

\section{KESIMPULAN}

Berdasarkan hasil penelitian melalui analisis deskriptif dan verifikatif dapat disimpulkan bahwa pengaruh Direct Mail dan Telemarketing terhadap keputusan pembelian paket umrah di Raka Tours and Travel dengan menggunakan regresi linier berganda dapat diambil kesimpulan sebagai berikut:

1. Direct mail menjadi sub variabel dengan skor tertinggi, karena jamaah merasakan secara langsung manfaat dari penawaran yang diberikan melalui media elektronik (email) ini. Dimana informasi yang diberikan menjadi acuan bagi calon jamaah sebagai salah satu tolak ukur dalam memutuskan pembelian paket umrah. Sedangkan sub variabel dengan nilai terendah adalah telemarketing, hal ini dikarenakan kepiawaian karyawan dalam memberikan informasi menjadi hal yang sangat mempengaruhi calon jamaah, kejelasan informasi yang diberikan hingga keramahan dari karyawan Raka Tours and Travel sendiri menjadi tolak ukur bagi jamaah dalam meneruskan komunikasi menjadi sebuah proses transaksi

2. Kontribusi paling tinggi dari diantara sub variabel keputusan pembelian adalah pilihan waktu dan pembelian, hal ini dikarenakan jamaah Raka Tours and Travel merasa tingkat kesesuain waktu umrah dengan waktu jamaah sudah cukup sesuai. Sedangkan sub variabel terendah adalah tingkat kesesuaian paket umrah dengan keinginan jamaah, hal ini dikarenakan tidak semua jamaah merasakan paket umrah dimana di dalamnya terdapat beberapa tempat yang diinginkan jamaah namun tidak tercantum dalam paket umrah Raka Tours and Travel.

3. Terdapat pengaruh yang positif antara direct marketing dimana di dalamnya terdapat dimensi direct mail dan telemarleting terhadap keputusan pembelian paket umrah Raka Tours and Travel, dikarenakan secara keseluruhan nilai $t_{\text {hitung }}>\mathrm{t}_{\text {tabel, }}$, artinya semakin baik pelaksanaan direct marketing dimana didalamnya terdapat direct mail dan telemarketing, maka akan semakin mempengaruhi keputusan pembelian paket umrah Raka Tours and Travel.

\subsection{Rekomendasi}

Berdasarkan hasil penelitian yang diperoleh dari temuan yang telah dihasilkan, maka penulis merekomendasikan hal-hal berikut ini dengan harapan akan memberikan kontribusi bagi kemajuan juga perkembangan Raka Tours and Travel sebagai salah satu Biro Perjalanan Wisata yang turut menyelenggarakan umrah di Kota Bandung. Rekomendasi yang dapat diberikan adalah sebagai berikut :

1. Pihak perusahan lebih mengoptimalkan divisi umrah dan haji yang dimiliki perusahaan. Dimana saat ini keberadaannya masih belum dirasakan maksimal dikarenakan tidak adanya staff khusus haji dan unrah yang dimiliki perusahaan. Sehingga pemasaran paket haji khususnya umrah tidak dilaksanakan secara terfokus dan memiliki target pasar yang jelas.

2. Mengupayakan keragaman paket umrah yang dimiliki perusahaan. Dengan adanya paket umrah yang beragam dapat dipastikan calon jamaah memiliki banyak pilihan dan dapat lebih mempertimbangkan paket umrah yang 
dimiliki dibandingkan paket umrah yang ada di perusahaan lain.

3. Meningkatkan keterampilan karyawan baik dalam menggunakan berbagai media untuk memasarkan paket umrah, juga dalam keterampilan karyawan dalam berkomunikasi baik secara telepon maupun secara langsung dengan perusahaan. Hal ini dirasakan penting, karena tenaga pemasar merupakan pembentuk image bagi perusahaan di mata calon jamaah.

4. Meningkatkan semua unsur yang terdapat dalam paket umrah. Seperti proses administrasi serta pembayaran sehingga jamaah merasakan kenyamanan dalam bertransaksi, selain itu fasilitas yang terdapat dalam paket seperti fasilitas hotel, fasilitas kendaraan yang digunakan hingga kualitas dari pembimbing umrah sendiri. Hal tersebut dimaksudkan untuk meningkatkan keputusan pembelian bagi calon jamaah.

5. Mengupayakan diadakannya pengajian atau pertemuan yang secara rutin dilaksanakan oleh perusahaan dengan beranggotakan jamaah yang telah menggunakan paket umrah, sehingga hubungan perusahaan dengan pelanggan dari paket umrah dapat terjalin dengan baik, selain itu kerjasama yang dibina dengan jamaah dapat menghasilkan input yang positif bagi perusahaan.

\section{DAFTAR PUSTAKA}

\section{Buku:}

Bennet, Anthony G. 2010. The Big Book Of Marketing : Lessons And The Best Practices From The World's Greatest Companies.New York : Mc Grow hill.

Buchari, Alma. 2007. Manajemen Pemasaran dan Pemasaran Jasa, Edisi Revisi. Bandung: Alfabeta

Canon, Prreault, Mcartney. 2009. Basic Marketing : A Marketing Strategy Planning Approach. New York : Irwin Mc-Graw Hill

Cravens, David W and Piercy. 2009, Strategic Marketing, international Edition, ${ }^{\text {th }}$ Ed.,Mcgraw-Hill Companies Inc., New York

Fandy Tjiptono dan Gregorius Chandra. 2008. Service, Quality \& Satisfaction. Yogyakarta: Andi.

Griffin, Ricky W dan Ronald J Ebert. 2007. Business $6^{\text {th }}$ Edition, Pearson
International Edition, New Jersey : Prentice Hall

Hurriyati, Ratih. 2010. Bauran Pemasaran dan Loyalitas Konsumen. Alfabeta. Bandung

Husein, Umar. 2008: Metode Penelitian untuk Skripsi dan Tesis Bisnis. Jakarta: Rajagrafindo Persada.

Lovelock, HI, Christoper, 2009. Service Marketing. $6^{\text {th }}$ adition, London:Prientice Hall International, Inc

Malhotra, Naresh K. 2007. Riset Pemasaran. PT.Indeks : Jakarta

Kotler And Amstrong. 2008. Marketing Management. $13^{\text {th }}$ edition, New Jersey:Prentice Hall

Amstrong. 2012. Principles of Marketing $14^{\text {th }}$ ed. Pearson Hall. New Jersey

Kotler dan Keller. 2012. Marketing Management $14^{\text {th }}$ ed. Pearson Hall, New Jersey

Lambin, Jean-Jacques. 2007. Market Driven Management : Supplementary Web Resource Material. Palgrave Macmillan

Mullin, Roddy. 2009. Sales Promotion, menciptakan, mengimplementasikan dan mengintegrasikan program promosi penjualan. PPM : Jakarta.

Pahliawan, Nogus. 2010. Pengaruh Program Direct Marketing Terhadap Keputusan Menggunakan Meeting Package Hotel Grand Preanger Bandung: Skripsi Sarjana FPIPS UPI, UPI BANDUNG: tidak diterbitkan

Saiki, Danyi 2008. Service Marketing. ABD Publisher

Saladin, Djaslim. 2006. Manajemen Pemasaran, Edisi Keempat. Linda Karya : Bandung

Sugiono.2010. Metode Penelitian Bisnis : Pendekatan Kuantitatif, kualitatif dan $R \& D$. Alfabeta : Bandung

Suharsimi Arikunto. 2009. Prosedur Penelitian, Suatu Pendekatan Praktek (Edisi revisi 5) Rineka Cipta : Jakarta

Sulastri,Cici.2009.Pengaruh Kinerja Paket Umrah dan Haji Khusus Terhadap Retensi Pelanggan PT. Amanah Mulia Wisata Sebagai Travel Penyelenggara Umrah dan Haji Khusus di Kota Bandung :Skripsi Sarjana FPIPS UPI, UPI Bandung : Tidak Diterbitkan

Schiffman,L,E dan Kanuk,LL,.2000. Customer Behaviour and Marketing Strategi, $3^{\text {rd }}$ edition:Home Wood 
Tjiptono, Fandy. 2008. Strategi Pemasaran Edisi III. Andi. Yogyakarta.

Ulbert Silalahi. 2009. Studi Tentang Ilmu Administrasi dan Manajemen. Sinar Baru Aglesindo : Bandung

\section{Sumber Lain :}

\section{Journal dan Artikel}

UNWTO 2011 : A Journal United Nations World Tourism Organizations Reports

George,Lancaster.2011. Direct Marketing

The Ballantine, Corporation.2010. An Article of Direct Marketing Trends for 2011

Hudson,Simon.2008.Tourism and Hospitality Marketing: A Global Perspective. London : SAGE Publications Ltd

Naik, Prasad A., Nanda Piersma. (2002) A Journal Understanding the role of marketing communications in direct marketing. Erasmus university of Rotterdam

\section{Dokumen :}

Undang-Undang RI No.10 Tahun 2009

Tentang Kepariwisataan

\section{Website :}

http://books.google.co.id www.bps.com

www.bandungtourism.com

www.rakatour. com

www.repository.upi. edu

www.unwto.com

www.menparekraf.com 